\title{
Verkkokeskustelujen kansa
}

\section{Korpusavusteinen diskurssianalyysi Suomi24-keskustelupalstasta}

\section{Johdanto}

Tässä artikkelissa tutkimme, miten sana kansa käsitetään Suomen suurimmalla keskustelufoorumilla ja millaisia diskursseja siihen liittyy. Kansa on ymmärretty antiikin ajoista lähtien ainakin kolmella tavalla: kansanjoukoksi, tavallisiksi ihmisiksi ja kansakunnaksi (Müller 2016, 22). Nykyiset verkkokeskustelut tarjoavat näkemyksen siitä, miten keskusteluihin osallistuvat representoivat kansaa tänä päivänä.

Internetin myötä mahdollisuudet kirjoittaa julkisesti ovat mullistuneet (ks. Kauranen 2013). Sosiaalisessa mediassa kansalaisten ilmaisemat mielipiteet muodostavat varsin suuren osan nykyistä julkista verkkokeskustelua, minkä vuoksi kirjoittajien käsitys kansasta on kiinnostava tutkimuskysymys. Lisäksi suuret aineistot, kuten tässä tutkimuksessa käytettävä Suomi24-keskustelupalstaan perustuva iso Suomi24-korpus (Aller Media Oy 2014; Lagus-Pantzar-Ruckenstein-Ylisiurua 2016), avaavat uudenlaisen näkökulman kansan määrittelyihin ja kansaan liittyviin diskursseihin.

Sosiaalisen median verkkokeskustelut ovat tilanteista, kirjoitettua sosiaalista vuorovaikutusta. Keskustelujen aiheet ja kielellinen toiminta vaihtelevat hyvin paljon keskustelupalstan alustalta toiselle, eivätkä keskustelut edusta mitään tiettyä yhtä keskustelutyyppiä (activity type, Levinson 1992; ks. Arendholz 2017; Johansson 2017). Näillä moninaisilla palstoilla keskustelijoiden kielenkäyttö on arkista ja epämuodollista, ja sitä voidaankin luonnehtia nykyaikaiseksi vernakulaariksi ilmaisuksi tai julkiseksi kansankieleksi (Coupland 2014; Johansson 2017, 8). Tämän lisäksi keskustelijat ilmaisevat kommenteissa omia tai kierrätettyjä näkemyksiä ajankohtaisista asioista, joihin heillä ei ole aina valtaa tai mahdollisuutta vaikuttaa (ks. Papacharissi 2014; Johansson 2017, 6-8). Toisin kuin internetin alkuaikoina toivottiin, mielipiteiden vaihdosta sosiaalisessa mediassa ei ole syntynyt sellaista kansalaiskeskustelua, jossa ratkottaisiin yhteiskunnallisia ongelmia (van Dijck-Poell 2013; Papacharissi 2014). Yhteiskunnallisista ja poliittisista aiheista käytävät verkkokeskustelut perustuvat hyvin usein irrallisten erimielisten mielipiteiden 
esittämiseen ilman, että keskustelijoiden välille syntyy minkäänlaista yhteisymmärrystä (Kleinke 2010; Johansson 2017, 5).

Tässä artikkelissa lähestymme kansaan liittyviä diskursseja korpusavusteisen ja laadullisen digitaalisen diskurssianalyysin keinoin. Monimenetelmällinen lähestymistapa valottaa aineistoa kahdesta näkökulmasta ja antaa mahdollisuuden esittää kaksi toisiaan täydentävää tulkintaa. Tutkimuskysymyksemme ovat seuraavat:

1) Millaisia diskursseja verkkokeskustelijat liittävät kansaan?

2) Miten kirjoittajat representoivat ja asemoivat kansaa eri diskursseissa?

Tutkimuksemme ytimessä on kahtalainen diskurssin käsite. Määrittelemme diskurssin tilanteiseksi kielenkäytöksi kontekstissa (Stubbs 2001, 11-13). Toiseksi ymmärrämme diskurssin dialogisena kielenkäyttönä ja merkityksen rakentamisena sosiaalisessa toiminnassa (Fairclough 1992, 128; ks. myös Stubbs 2001, 5; Partington-Duguid-Taylor 2013, 2-3). Käytämme suppeampaa diskurssin käsitettä korpusavusteisessa analyysissämme (luku 4) ja laajempaa määritelmää digitaalisessa diskurssianalyysissä (luku 5). Eri diskurssit tai diskurssityypit liittyvät diskurssin käsitteeseen. Tällä tarkoitamme tekstin tai vuorovaikutuksen sisältöä, ominaisuuksia ja jäsennystä (Östman-Virtanen 2011, 275). Diskurssityypit ovat eri alojen diskursseja, kuten uskonnollinen tai poliittinen diskurssi. Representaatiolla tarkoitamme sosiaalisia, kogniitivisen tietämisen muotoja, jotka voivat koskea useita erilaisia asioita (yksilöitä, yhteisöjä, käsitteitä jne.) ja jotka voivat olla yksilöllisiä tai yhteisöllisiä (van Dijk 2006, 128).

Käsittelemme ensiksi sitä, miten kansa on määritelty ihmistieteissä kielitieteestä folkloristiikkaan (luku 2), minkä jälkeen esittelemme teoreettisen viitekehyksen, aineiston ja käytetyt menetelmät (luku 3). Analyysi käsittää avainsanojen ja diskurssiprosodioiden tarkastelun (luku 4) ja sen, miten kansaa representoidaan ja mikä sen merkitys on sosiokulttuurisessa konteksteissa (luku 5). Näistä merkityksistä muodostuvat verkkokeskusteluissa esiintyvät näkemykset kansasta suurimmalla suomalaisella keskustelufoorumilla. Artikkeli päättyy johtopäätöksiin (luku 6).

\section{Monitulkintainen kansa-käsite}

\subsection{Kaksijakoinen kansa}

Näennäisestä neutraalisuudestaan huolimatta kansa on monitulkintainen ja varsin monisyinen käsite, jota on yritetty määritellä vuosisatojen ajan. Monitulkintaisuutensa sekä historiallisten ja ideologisten painolastiensa vuoksi on jopa esitetty, että koko termiä ei tulisi edes käyttää tieteellisenä käsitteenä (Knuuttila 2008 [1982], 405). Määritelmät riippuvat määrittelijöistä ja heidän tarkoitusperistään: Halutaanko määritelmällä yhdistää ihmisryhmiä vai erottaa? Sijoittaako määrittelijä itsensä kansaan kuuluvaksi vai ei? (Kurki 2002, 52-58; Mikkola 2009, 37.) Kysymys on myös siitä, näyttäytyykö määriteltävänä 
oleva kansa yksilöiden välisenä vuorovaikutuksena vai laadullisena kollektiivina (Knuuttila 1992, 47-48). Tätä jatkuvaa määrittelyä nimitetään kansapuheeksi (Anttila-Kauranen-Löytty-Pollari-Rantanen-Ruuska 2009, 21). Politiikassa nykyisille populistipuolueille on tyypillistä vetoaminen kansaan ja kansan tahtoon. Populistit näkevät itsensä eliitin vastakohtina, kun taas aiemmin nimenomaan eliitti pyrki erottamaan itsensä kansasta. (Müller 2016; ks. myös lukua 2.2.)

Sanaa kansa käytetään usein merkityksessä 'jonkin seudun asukkaat', 'tavalliset ihmiset' tai 'me suomalaiset', mutta sillä voidaan tarkoittaa yhtä lailla alempaa yhteiskuntaluokkaa. Kansalla tarkoitetaan myös 'ihmis- tai kansajoukkoa' tai 'kansakuntaa' (Kauranen 2013, 25-26; Tieteen termipankki, kielitiede s.v. kansa). Kielitoimiston sanakirja (KS sv. kansa) määrittelee kansan 'kulttuuriltaan ja kieleltään yhteen kuuluvaksi ihmisryhmäksi, jonkin valtion väestöksi, seudun asukkaiksi, väeksi, työväeksi, alemmaksi yhteiskuntaluokaksi tai suureksi ihmisjoukoksi. Erityisesti alemmista yhteiskuntaluokista koostuvaa kansaa on määritelty valtaapitävien ja yhteiskunnan eliitin piirissä jo satojen vuosien ajan uskonpuhdistuksen, valistuksen, kansallisromantiikan sekä kehitysoptimismin näkökulmista (Kurki 2002, 52-58; Liikanen 2003, 257-258). Näissä määritelmissä kansaa kuvattiin usein vastakohtien avulla: eliitti oli sivistynyttä ja oppinutta ja pyrki jatkuvasti kehittymään, kun taas kansa oli sivistymätöntä ja oppimatonta eikä kyennyt kehittymään (Kurki 2002, 52-58).

Zacharias Topeliuksen Maamme kirjassa (1876) kuvaama kansa koostuu "erisukuisista ja erikielisistä" kansanryhmistä:

Tässä maassa asuu siis erisukuista ja erikielistä kansaa - - Harvat ovat niin sekoittumatonta sukuperää, ettei heidän suvustaan jonkun suonissa ole virrannut eri kansakuntain verta. Mutta se on sanottu, että kaikki, jotka tunnustavat tämän maan isänmaakseen ja rakastavat tätä sellaisena, - kaikki, jotka tottelevat tämän maan lakia ja tekevät työtä tämän hyväksi, - ovat yksi kansa. (Topelius 1876, 71.)

Seuraavina vuosikymmeninä Topeliuksen näkemys sai kuitenkin väistyä ja suomalaisista ryhdyttiin rakentamaan kansallisromantiikan ja nationalismin hengessä kulttuurisesti ja kielellisesti yhtenäistä kansaa muun muassa keräämällä suullista perinnettä ja kansanrunoutta sekä kodifioimalla kirjakieli (ks. esim. Anttonen 2005, 81-94, 161-166; Mikkola 2009, 37-38; Tervonen 2014, 138-143). Yksi keskeisiä kansallisen identiteetin rakentajia oli Elias Lönnrot (Karkama 2001). Autonomisen Suomen suuriruhtinaskunnassa kansan yhtenäisyyden korostamisella oli myös poliittisia tavoitteita. (Liikanen 2003, 271.)

Vuosisadanvaihteessa julkisessa keskustelussa pohdittiin, muodostuiko kansa esimerkiksi rodun, kielen vai maantieteellisten rajojen mukaan. Vai tarvittiinko kansan yhdistämiseksi yhteinen historia? Tällä tavoin määrittelemällä voitiin ihmisryhmiä sekä yhdistää että erottaa. Esimerkiksi sortotoimien aikana esitetty ajatus yhteisen kärsimyksen yhdistämästä suomalaisesta kansasta oli yritys ylittää kieli- ja luokkaerot poliittisten tavoitteiden ajamiseksi. (Anttila ym. 2009, 18-19.) Silloinkin, kun yhteisten tavoitteiden ajamiseksi kansalla viitattiin koko Suomen väestöön, pysyi kuva kansasta silti kaksijakoisena. Yhtäältä kansaan kuuluvia ihannointiin ja toisaalta heitä paheksuttiin ja väheksyttiin (Apo 1998, 
88-89; Tieteen termipankki, folkloristiikka s.v. kansa). Etenkin kansaan kuuluvia talonpoikia ihailtiin ahkerina, raittiina, siveellisinä, rehellisinä, valistettavina ja kunnollisina, kun taas maattomia ja kaupunkien työläisiä pidettiin kehittymättöminä, laiskoina, impulsiivisina, aggressiivisina sekä "alhaisia mielihaluja" toteuttavina. Pahinta oli, että nämä ryhmät ryhtyivät sosialismin levitessä järjestäytymään ja vaatimaan itselleen oikeuksia ja valtaa. Sisällissodan syttyessä ero näiden kahden kansan välillä kärjistyi entisestään, kun talonpojat liittyivät valkoisiin ja työläiset punaisiin. (Apo 1998, 91-92, 96, 101-102, 117.) Yleisen käsityksen mukaan taistelu yhteistä vihollista Neuvostoliittoa vastaan eli "talvisodan ihme" yhdisti jälleen kansan (Apo 1998, 117). Käsitys "poikkeuksellisen yhtenäisestä" Suomen kansasta on elänyt näihin päiviin asti. Tämän käsityksen rakentamiseen ja ylläpitämiseen ovat osallistuneet myös eri alojen tutkijat, kuten kansallisten tieteiden edustajat ja historioitsijat. (Anttonen 2005, 87-88; Tervonen 2014, 137-162.)

Kansa on aktiivisesti vastustanut yhteiskuntaluokkaansa ja elämäntapaansa kohdistuvaa kritiikkiä. Folkloreaineistoissa on lukemattomia anekdootteja, kaskuja ja sananlaskuja, joissa pilkataan ja ivataan herroja ja herrojen tapoja. Herrojen ohella arvostelun kohteena ovat olleet papit, nimismiehet, tuomarit ja muut virkavallan edustajat. Kansaan kohdistettu kritiikki käännetään näissä usein nurin päin: likaisuus kuvataan merkiksi työteliäisyydestä ja vanhojen ja paikattujen vaatteiden käyttö merkiksi säästäväisyydestä ja tarkasta taloudenpidosta. (Mikkola 2009, 247; ks. myös Apo 1995; Knuuttila 1994; Pöysä 1997.) Tarkastellessaan kansanretoriikkaa eli niitä politiikkaa koskevia puhetapoja, joilla ihmiset kommentoivat valtiollista politiikkaa, arvioivat poliitikkoja ja selittävät historiallisia ja ajankohtaisia asioita yksilö- ja yhteisötasolla, Pauliina Latvala (2013, 29-30, 33-36) huomauttaa, että kansan poliitikkoja koskeva arvostelu on ollut rajua (mt., 220-221.)

\subsection{Kansa nykyisessä populistisessa diskurssissa}

Nykyisin sana kansa esiintyy tiuhaan populistisessa poliittisessa diskurssissa, eikä sen merkitys ole kovin yksiselitteinen. Populismi tarkoittaa eri maissa hyvin erilaisia poliittisia suuntauksia: se voidaan liittää vahvoihin ja karismaattisiin johtajiin, poliittisiin puolueisiin tai ruohonjuuritason poliittiseen aktiivisuuteen, kuten teekutsuliikkeeseen Yhdysvalloissa (Müller 2016, 9). Keskitymme tässä ainoastaan populistisen diskurssin luonteeseen ja sen yleisimpiin väitteisiin kansasta. Jan-Werner Müllerin (2016, 19-20) mukaan keskeisintä populismissa on moraalinen ja yhtenäinen maailma, jossa kansa asetetaan korruptoitunutta ja moraalisesti arveluttavaa eliittiä vastaan. Ainoastaan populistit voivat edustaa kansaa: "There can be no populism, in other words, without someone speaking in the name of the people as a whole" (mts. 20). Kuitenkaan kukaan ei tunne "koko kansaa" tai kaikkia kansan jäseniä: kansa ja kansakunta ovat representaatioita, tai kuvitteellisia yhteisöjä, kuten Benedict Anderson (1983) asian ilmaisee.

Populismi esiintyy aina edustuksellisen politiikan "varjona" tavoitteenaan haastaa muita politiikan toimijoita (Müller 2016, 101). Patrick Charaudeaun (2011) mukaan populistinen diskurssi nousee esiin ja voimistuu erityisesti yhteiskunnallisten kriisien 
yhteydessä. Samoin se pyrkii osoittamaan demokraattisten järjestelmien epäkohtia (Müller 2016, 76). Populistiselle diskurssille on ominaista ideologinen yhtenäisyys, uskottavan ja kiinnostavan omakuvan rakentaminen ja omien arvojen esiintuominen.

Populistinen diskurssi voidaan myös kuvata tyytymättömyyden diskurssiksi, joka on epätarkkaa ja joka kohdistuu salajuonien ja vääryyden paljastamiseen. Siksi populisti esittää itsensä usein uhrina tai väärinkohdeltuna. (Müller 2016, 42.) Populisti etsii myös vastustajia, jotka ovat syyllisiä. Vastustajia ovat eristäytynyt eliitti, kapitalistit tai omasta kannasta poikkeavat poliittiset toimijat. (Charaudeau 2005; 2011.) Populistinen diskurssi pyrkii polarisoimaan ja valmistelee jyrkkää vastakkainasettelua ja konfrontaatiota (Müller 2016, 42). Charaudeaun (2011) mukaan populistisessa diskurssissa on kolme päätavoitetta: vastustajien osoittaminen epäuskottaviksi, kansan arvon palauttaminen ja oman aseman legitimointi. Populisti on kansan johtaja, joka palauttaa kansalle menetetyn voiman ja päätösvallan, jotka yhteiskunnallinen koneisto, eliitti, on vienyt. Täten populistinen diskurssi on myös hyvin moralistista ja moralisoivaa diskurssia (Müller 2016, 42). Populistilla on ideaali "oikeasta" kansasta, jolla on historia, traditio, ja joka on sen vuoksi oikea ja autenttinen. (Charaudeau 2011; Müller 2016). Poliittisen, yksiarvoisen maailmankäsityksen mukaan populistit ovat ainoa oikea taho edustamaan moraalisesti oikeamielistä ja erehtymätöntä todellista kansaa (Müller 2016, 20).

Historialliset representaatiot kansasta (luku 2.1) sekä populistisen diskurssin representaatiot kansasta (luku 2.2) rakentavat ideologisia näkemyksiä. Osana ideologioita käsitykset kansasta tuottavat eri ryhmien omakuvia, jäsentävät identiteettejä, toimintaa, normeja ja suhteita muihin ryhmiin (van Dijk 2006). Ne ovat suhteellisen pysyviä, minkä avulla ryhmien jäsenet voivat jäsentää yhteisiä toimiaan ja vuorovaikutusta (mts. 117).

\section{Monimenetelmällinen lähestymistapa ja aineisto}

Tutkimuksessamme käytämme kahta menetelmää, korpusavusteista ja digitaalista diskurssianalyysiä. Monimenetelmällisissä tutkimuksissa yhdistetään yleensä kvantitatiivisia ja laadullisia menetelmiä (Creswell 2013, 14-16; Johansson-Kyröläinen-Ginter-LehtiKrizsán-Laippala 2018), ja niin tehdään tässäkin tutkimuksessa. Monimenetelmällistä lähestymistapaa voidaan soveltaa laajojenkin korpusten analyysiin.

Laajat tekstiaineistot eli korpukset yhdistyvät diskurssintutkimukseen korpusavusteisessa diskurssintutkimuksessa (corpus-assisted discourse studies, CADS). Menetelmässä käytetään laajoja sähköisiä tekstiaineistoja ja korpusmenetelmiä yhteiskunnassa yleisten ja jaettujen merkitysten selvittämiseksi. CADS yhdistää siis kaksi lähtökohdiltaan erilaista tarkastelutapaa: etupäässä laajojen tekstimassojen analyysiin soveltuvat kvantitatiiviset menetelmät ja diskurssintutkimuksen laadulliset menetelmät. (CADS:sta mm. McEneryXiao-Tono 2006, 111-113; Lee 2008, 86-87; Partington ym. 2013, 10-11; Jantunen, painossa.) Niin sanotulle perinteiselle diskurssintutkimukselle ja korpustutkimukselle on kuitenkin yhteistä se, että aineistoina käytetään todellisia tekstejä ja tulkinnat nojaavat toisteisuuteen ja säännönmukaisiin esiintymiin (Jantunen, painossa). 
Tarkastelemme sanan kansa esiintymiä aineistonamme Suomi24-korpus (Aller Media Oy 2014; Lagus ym. 2016), joka on koottu Kielipankkiin Kansakunnan mielenliikkeet (HY) -hankkeessa Korp-hakukäyttöliittymän kautta käytettäväksi. Korpus on avoin tutkimusaineisto, joka on luotu Suomi24-keskustelufoorumista. Foorumilla on noin 1,4 miljoonaa käyttäjää viikoittain, ja se on Suomen suosituin verkkokeskustelufoorumi. Aineistomme on vuosilta 2001-2016, ja se käsittää 2,4 miljardia sanetta. Ensimmäistä korpusavusteista analyysiä varten eristimme tekstikappaleet, joissa sana (lemma) kansa esiintyy. Yhteensä kansa-sanan esiintymiä on noin 829000 . Toisessa, digitaaliseen diskurssianalyysiin perustuvassa osiossa käytämme Korp-palvelimen 1 ooo:ta ensimmäistä konkordanssiesiintymää kansasta. Koska toisessa analyysissä lähestymistapa on laadullinen, tässä ei tavoitella tilastollista otantaa. Näistä esiintymistä poistettiin ensiksi toistuvat lauseet, jotka olivat keskusteluketjujen edeltävien kommenttien toistoa. Analyysissä aineistoesimerkit esitetään sellaisenaan korjaamatta kielivirheitä.

Tutkimuksessa aineistoa lähestytään kahdella tavalla. Ensiksi käydään läpi koko aineisto korpusavusteisessa diskurssianalyysissä (lukua 4). Kansa-sanan käyttöä tarkastellaan avainsana-analyysin (keyword analysis) avulla. Avainsanat ovat ilmauksia, jotka kuvaavat aineistoa tilastollisesti nimenomaan sanaston näkökulmasta: menetelmä paljastaa ilmaukset, jotka esiintyvät tutkimusaineistossa odotettua useammin tai harvemmin vertailuaineistoon nähden (ks. Scott-Tribble 2006) ${ }^{1}$. Avainsanat kuvaavat muun muassa tutkittavan aineiston sisältöä, tekstilajipiirteitä tai kielivarianttipiirteitä (ks. sisältö-, genre- ja kielivarianttiavainsanoista Jantunen 2011). Tässä analyysissä avainsanojen ajatellaan heijastavan kansa-sanan käyttöön liittyviä diskursseja. Avainsanat on laskettu vertaamalla kappaleiden sanastoa koko Suomi24-aineistoon, ja saneiden sijasta on käytetty Finnish Dep Parserin (Luotolahti-Kanerva-Laippala-Pyysalo-Ginter 2015) tunnistamia lemmamuotoja. Avainsanoista on tarkasteluun otettu 300 merkitsevintä lemmamuotoa.

Avainsanat on ryhmitelty tässä tutkimuksessa merkitysryhmiin, joiden avulla päästään kiinni niin sanottuihin diskurssiprosodioihin. Niillä tarkoitetaan sanojen ominaisuutta esiintyä tietyissä diskursiivisissa konteksteissa, mikä voi kertoa kielenkäytön funktioista tai asenteista (Stubbs 2001, 65-66). Kun on haluttu erityisesti korostaa ilmauksen kontekstisidonnaisuutta ja merkityksen muodostumista sanaa laajemmasta kokonaisuudesta, ilmiöstä on myös käytetty nimityksiä semanttinen preferenssi ja semanttinen prosodia riippuen tarkastelun tarkkuudesta (mm. Sinclair 1996, 87-88). Evaluatiivinen prosodia -termillä (mm. Partington ym. 2013, 58-61) korostetaan puolestaan arvottamista ja tekstin evaluatiivista harmoniaa diskurssin tuottamisessa. (Ks. myös Hunston 2007; Stubbs 2001, 65-66.) Nimenomaan diskursseihin keskittyvässä tutkimuksessamme pitäydymme diskurssiprosodia-käsitteessä (luku 4).

1 Sanojen frekvenssien ero tutkimusaineiston ja vertailuaineiston välillä todennetaan tilastollisella testillä, joka varmistaa, että ero ei johdu sattumasta. Tavallisesti testinä käytetään log-uskottavuutta (ks. http://ucrel.lancs.ac.uk/llwizard.html). Tätä käytämme myös tässä artikkelissa. 
Tutkimuksen digitaaliseen diskurssianalyysiin perustuvassa analyysissä (luku 5) kansan esiintymiä tarkastellaan merkityskontekstissa pragmaattisesta lähtökohdasta (Thurlow-Mroczek 2011; Helasvuo-Johansson-Tanskanen 2014; Hoffmann 2017, 6). Analysoimme, miten kansa kontekstualisoidaan eri diskurssityypeissä. Otamme huomioon avainsana-analyysin tuloksia tarkastellessamme, miten kielellinen toiminta ilmaistaan ja mitä kansalla tarkoitetaan kontekstissa (Gumperz 1992, 43-45; van Dijk 2006). Tässä analyysissä kiinnitämme huomiota ensisijaisesti lausetyyppeihin, verbeihin, määreisiin tai muihin kielellisiin elementteihin siinä, miten ne rakentavat merkitystä (ks. van Dijk 2006). Kiinnitämme huomiota siihen, miten kansan esiintymät asemoidaan. Asemoinnilla tarkoitetaan sitä, miten toimijat esittelevät itsensä tai toisensa tietyssä tilanteessa ja miten he indeksoivat oman toimijuutensa (Goffman 1990 [1959]; Harré-Langenhove 1999). Asemointi voi olla eksplisiittisesti ilmaistua tai se voi olla implisiittistä, epäsuoraa. Asemoinnilla toimijat voivat ilmaista myös suhdetta toisiin (relationaalisuus) ja sitä, miten he suhtautuvat asiaan (samanmielisyys-erimielisyys) (DuBois 2007, 163; Weizman 2008, 14). Analyysissä nousee esille myös suhde valtaan. Valta nähdään diskursiivisena, eli toimijoiden suhde valtaan voidaan merkitä diskurssissa esimerkiksi asymmetrisenä suhteena tai muilla tavoin (Fairclough 1992, 203; van Dijk 2006, 117).

\section{Avainsanoista diskursseihin}

Tässä luvussa tarkastellaan merkitysryhmiä, joita avainsanat muodostavat. Tätä varten analyysiin otettiin 300 avainsanaa. Näistä osa paljastui lähemmän tarkastelun jälkeen vain yhden kirjoittajan tai muuten toisteisen viestinnän esiin nostamiksi sanoiksi, ja ne poistettiin tarkastelusta. Jäljelle jäi 269 avainsanaa, jotka jaettiin merkitysryhmiin. Merkitysryhmät, niiden frekvenssit ja osuudet kaikista avainsanoista esitellään taulukossa 1.

Taulukko 1. Avainsanojen jakautuminen merkitysryhmiin.

\begin{tabular}{|l|l|l|}
\hline Merkitysryhmä & Frekvenssi & Osuus \% \\
\hline Uskonto & 119 & 44 \\
\hline Poltiikka ja valta & 64 & 24 \\
\hline Etnisyys & 17 & 6 \\
\hline Yhteiskunta & 16 & 6 \\
\hline Paikka & 9 & 3 \\
\hline Määrä & 7 & 3 \\
\hline Henkilö & 6 & 2 \\
\hline Kaupankäynti & 5 & 2 \\
\hline Luonne & 4 & 2 \\
\hline Aika & 3 & 1 \\
\hline Muut & 19 & 7 \\
\hline Yhteensä & 269 & 100 \\
\hline
\end{tabular}


Merkitysryhmistä selvästi suurin on uskonto, joka kattaa lähes puolet tarkastelluista avainsanoista. Tämä sisältää sekä raamatullisiin henkilöihin viittaavia nimiä, kuten Efraim tai Jooel, viittauksia raamatun jakeisiin (29:18), juutalaisuuteen liittyviä sanoja (lehtimajanjuhla, pakkosiirtolaisuus), paikkoja (Babylon, Assyria), uskonnollisia ryhmiä (hebrealainen, itäjuutalainen) ja uskonnolliseen kieleen kuuluvia kehotuksia (menkäät, opettakaat). Lisäksi tässä merkitysryhmässä on runsaasti muita uskontoon liittyviä sanoja, kuten jumalaapelkääväinen, pakanakansa, palmunoksa, teurasuhri ja valheprofeetta. Aineiston valossa näyttää siis siltä, että uskonnollinen diskurssi on voimakkaasti läsnä kansasta puhuttaessa: kansaa representoidaan paljolti uskonnollisena yhteisönä ja siihen liitetään uskonnolliset tapahtumat ja teokset tai kansaa käsitellään uskonnollisissa teoksissa, lähinnä Raamatussa.

Toinen suuri merkitysryhmä ja siten avainsanojen esiin nostama diskurssiprosodia on politiikka ja valta. Avainsanoissa näkyvät hallintoon ja hallintoelimiin viittaavat sanat (hallintokoneisto, kansanäänestys, puoluevalta, vallanpitäjä, valtiopäivät, hajotti, karkottaa [maasta]), itsenäisyys ja siihen nykypäivänä ja historiallisesti liittyvät ideologiat (kansallisuusaate, kansansuvereniteetti, Suur-Suomi) ja ulkomaiset tahot, jotka liittyvät tiiviisti Suomen politiikkaan (EU, Nato-jäsenyys). Lisäksi merkitysryhmä sisältää sanoja, jotka viittaavat ulkomaihin ja ulkomailla tapahtuvaan toimintaan (vaalitarkkailija, länsimielinen). Monet sanat viittaavat myös kansan kahtiajakoon (loiseliitti, oligarkki, riistopolitiikka, valtaeliitti) tai heijastavat voimakasta, usein negatiivisesti sävyttynyttä toimintaa, jossa kansa on sorron kohteena (kauhistaa, kurjistaa, köyhdyttää). Näiden perusteella kirjoittajat liittävät kansaan kriittisiä käsityksiä yhteiskunnasta ja sen jakautumisesta. Lisäksi muutaman avainsanan perusteella kansasta keskustellaan impulsiivisena ja helposti innostuvana (villitä, juovuttaa).

Verkkokeskustelujen kansaan liittyy siis selvästi poliittinen diskurssi, mikä tukee monia luvussa 2 esitettyjä aiempia tulkintoja ja pohdintoja kansan käsitteestä. Ensinnäkin avainsanojen perusteella voidaan arvioida, että hallinto ja ideologiat ovat keskeisiä tekijöitä siinä, miten kansa ymmärretään verkkokeskusteluissa (ks. myös lukua 5). Lisäksi yhteiskunnan epätasa-arvoon viittaavat avainsanat vahvistavat, että kansan käsite liitetään verkkokeskusteluissa vahvasti myös Müllerin (2016) kuvaamaan populistiseen näkemykseen poliittisesta diskurssista, jossa kansan kahtiajaolla ja epätasa-arvolla on selvä rooli. Nykypäivän populismin lisäksi avainsanat viittaavat myös piirteisiin, joilla kahtiajaossa vähäosaisempaa kansanosaa on kuvattu historiassa.

Näiden kahden suuren merkitysryhmän jälkeen tulevat ryhmät ovat selvästi pienempiä. Etnisyys ja yhteiskunta kattavat molemmat $6 \%$ avainsanoista. Etnisyys pitää sisällään useita kansalaisryhmiä (indoeurooppalainen, arabikansa, suomensukuinen), yleisesti aiheeseen viittaavia sanoja (kansallistunne, heimoaate) ja muita ihmisryhmiin liittyviä avainsanoja (heimo, kansakunta). Yhteiskunta taas sisältää yhteiskunnan eri kerroksiin liittyviä sanoja (työväestö, sulatusuuni) sekä maanpuolustusta ja oikeusjärjestelmää merkitseviä sanoja (puolustustahto, Valtionoikeus). Lisäksi, samoin kuin politiikka ja valta -merkitysryhmään, myös yhteiskunta-merkitysryhmään kuuluu yhteiskunnan kahtiajakoon viittaavia termejä (rahaeliitti, pummieliitti, orjakansa, veropakolainen). Osa 
yhteiskunta-kategoriaan luokitelluista sanoista voitaisiin ryhmitellä myös poliittisiksi sanoiksi, koska muun muassa talouteen liittyvät päätökset ovat yleensä juuri poliittisia päätöksiä. Ryhmittelyssä on kuitenkin lähdetty liikkeelle perusmerkityksestä, ja siten ryhmät on pidetty erillään; samalla on päästy hienojakoisempaan jaotteluun. Jos ne taas halutaan nähdä yhtenä kokonaisuutena, kasvaa vallan ja politiikan diskurssin osuus entistä suuremmaksi.

Loput merkitysryhmät ovat pieniä. Paikka-, määrä- ja henkilö-ryhmät sisältävät nimiensä mukaisesti paikkoja (puronnotko, asuma-alue) ja paikkakuntia (Satakunta, Palestiina), määrää ilmaisevia sanoja (viisimiljoonainen) ja henkilöitä (Grimberg, Aurejärvi). Pienimmät merkitysryhmät kaupankäynti, luonne ja aika käsittävät joitain viittauksia kauppaan (asebisnes, eurovaluutta), kansojen luonteeseen (katajainen, uppiniskainen) ja ajan ilmauksiin (aamurusko, huomispäivä).

\section{Kansan representaatiot ja asemointi eri diskurssityypeissä}

Digitaaliseen diskurssianalyysiin perustuvassa tarkastelussa aineistosta nousevat esiin uskonnollinen, poliittinen ja yhteiskunnallinen diskurssi. Analyysissä erotettiin pääasialliset asemoinnit ja representaatiot, jotka osoittavat, miten kansa ilmaistaan suhteessa valtaan ja millainen toimijuus kansalle annetaan. Seuraavassa avaamme näiden keskeisimpien kontekstualisointien merkityksiä lähemmin aloittamalla uskonnollisista diskursseista.

\subsection{Uskonnollinen diskurssi}

Kirjoittajat asemoivat kansaa historiallisena tai uskovana kansana:

1) Israelin kansa oli Vanhan Testamentin aikana Jumalan luvattu kansa

2) Juutalaiset ovat erityisasemassa, koska ovat Jumalan valittu kansa.

Esimerkit 1-2 ovat sellaisia, joissa kirjoittaja tulkitsee kansaa raamatullisessa, intertekstuaalisessa merkityksessä. Kuten jo luvussa 4 kävi osittain ilmi, paikannimet (Israel), uskonnolliset ryhmät (juutalaiset) ja viittaukset uskonnollisiin auktoriteetteihin ja henkilöihin (jumala, herra) ovat aineistossa yleisiä. Nämä esimerkit kuvaavat joko kansaa ihmisjoukkona tai kansan ryhmäidentiteettiä. Aineistossa on myös useita suoria sitaatteja Raamatusta (ks. myös lukua 4).

Verkkokeskustelu sisältää kuitenkin myös uskontoteemaisia asemointeja, joissa kirjoittaja kuvaa uhriutumista ja syyllistää:

3) Mitä pahaa me Herran kansa olemme tehneet sen ansaitaksemme?

4) No onhan tämä kansa unohtanut, kirkot ammottaa tyhjyyttään, synti rehottaa kirkon johtoa myöten.

Esimerkissä 3 kirjoittaja lukee itsensä osaksi Herran kansaa ja tekee subjektiivisen tulkinnan. Hän esittää retorisen kysymyksen, jossa hän asemoi itsensä kansan joukkoon 
me-pronominin avulla. Kysymys sisältää erimielisyyden ilmauksen ja kyseenalaistuksen (mitä pahaa), minkä vuoksi siitä välittyy Herran kansan kokema vääryys ja uhrin asema. Esimerkissä 4 kirjoittaja arvioi kansan etääntymistä uskonnosta, mitä hän kuvaa kognitiivisella verbillä unohtaa. Tämä esimerkki sisältää myös epäsuoran syytöksen (synti rehottaa), jossa kirjoittaja on tyytymätön vallitsevaan uskonnollisen asenteeseen.

\subsection{Poliittinen ja yhteiskunnallinen diskurssi: kansa ilman valtaa}

\subsubsection{Tyhmä kansa}

Kansaa määritetään usein adjektiivilla tyhmä toteamuksissa, huudahduksissa tai retorisissa kysymyksessä, jolloin viitataan kansalliseen ryhmään. Kansa ei ole kuitenkaan pelkkä ihmisjoukko tai ryhmä tavallisia ihmisiä. Ensimmäisen asemoinnin muodostaa eräänlainen kansan omakuva tai kirjoittajan havainnoima kuva Suomen kansasta (esimerkit 5-9):

5) Uskomattoman tyhmä kansa nimeltä Suomi.

6) Suomen kansa on tyhmää.

7) On tämä kansa tyhmää!

8) Ei Suomen kansa voi olla oikeasti näin tyhmää!

9) Siis että Suomen kansa olisi umpityhmää?

Aineiston tyhmän kansan ilmauksissa on myös merkityksiä, joissa kansa jää ulkopuoliseksi yhteiskunnallisesta toimijuudesta. Ulkopuolisuus toteutuu suhteessa yhteiskuntaan, jossa kansalla ei ole valtaa. Kansa asemoidaan ymmärtämättömäksi kielteisissä ja pejoratiivisissa yhteyksissä:

10) Ei tyhmä kansa huomaa mitä on tekeillä ja mistä globalisaatiossa on kyse.

11) Tyhmä kansa ei ymmärrä politiikkaa, poliittisia päätöksiä.

12) Tyhmä kansa ei huomaa, mitä on tekeillä.

13） Tyhmää kansaa käytetään hyväksi.

14） Joo, kyllä, tämä kansa on tyhmää ja kaikenmaailman pekkaperät käyttävät sitä hyväkseen surutta.

Esimerkeissä 10-12 on kognitiivisia verbejä (ymmärtää, huomata), joilla kuvataan kansan rajallista kapasiteettia ymmärtää poliittisia toimia. Kansa on myös poliittisten toimien passiivinen kohde, joka ei ymmärrä puolustautua, mikä ilmaistaan esimerkeissä 13-14 ilmaisulla käyttää hyväksi. Näissä asemoinneissa kirjoittaja valittaa, millaista kansa on. Valittaminen onkin tyypillistä kielellistä toimintaa tässä osassa aineistoa. Sen avulla kirjoittaja ilmaisee voimakkaan mielipiteensä kansan ymmärtämättömyydestä ja asemasta, jolle ei voi mitään, kuten ilmenee seuraavista esimerkeistä 15-16: 
15) Suomen kansa ei ymmärrä kuin kurituksen kautta, mitä tekevät.

16) Suoman [Suomen] kansa on herkkäuskoista ja helposti johdateltavissa olevaa porukkaa.

Tässä käsitys kansasta kehittymättömänä ja impulsiivisena palautuu vanhaan näkemykseen kansasta (vrt. lukua 2). Tyhmän ja ymmärtämättömän kansan tekojen seuraukset ovat valituksen kohteena, erityisesti poliittisissa yhteyksissä:

17) Tyhmä kansa ansaitsee arvoisensa koaliittion joka tässätapauksessa on EU.

18) Vittu että kansa on sitten saatanan tyhmää ja Kokoomus senkun porskuttaa :)

Esimerkeissä 17-18 kansa ja sen tyhmyys liitetään poliittisiin toimijoihin. Tyhmyys on suhteessa vääränlaisiin päätöksiin, joita kansa on tehnyt, kuten myös seuraavissa esimerkeissä 19-20, joissa ei ole adjektiivia tyhmä, vaan tyhmyys ilmaistaan toisin:

19) Pohjolassa asuu sinisilmäisten hölmöläisten kansa joka mieluusti maksaa kreikkalaisten elämisen.

20) Onko kansa tolloa, kun antaa kusitolppien ja hallitusten näin toimia vain varakkaiden ehdoilla?

Esimerkeistä 19-20 käy ilmi, että kansaa petetään ja että kansa maksaa. Palaamme näihin teemoihin seuraavassa alaluvussa.

Verkkokeskustelun tyhmän kansan merkitys on siis lähellä ymmärtämätöntä ja sivistymätöntä kansaa tai rahvasta (ks. lukua 2). On mielenkiintoista, että kirjoittajat asemoivat itsensä useimmiten tyhmän kansan ulkopuolelle, eli he itse eivät kuulu tähän joukkoon. Tämän vuoksi he pystyvät arvostelemaan tietämätöntä kansaa. Verkkokeskustelussa siis uusinnetaan kansaan kohdistuvaa paheksuvaa ja väheksyvää suhtautumista. Kirjassaan Tyhmän kansan teoria Seppo Knuuttila $(1992,26-27)$ huomauttaa, että kansanihmisiin on ollut taipumus suhtautua kahtalaisesti: yksilöinä järkevinä ja ajattelevina, mutta joukon jäseninä heitä on pidetty yhtä aikaa myös tyhminä ja harhaanjohdettavina.

\subsubsection{Kansa uhrina ja petettynä}

Tyhmän kansan lisäksi kirjoittajat kuvaavat kansaa joko uhrina, joka kärsii tai jota on petetty:

21) Viis siitä, jos kansa kärsii nälkää ja kuolee kurjuuteen.

22) Vaikka oma kansa työttömänä ja eläkeläisiltä viedään leipä suusta.

23) Samaan aikaan kansa täällä pohjolassa kärsi laman kourissa.

24) Suomessa huonot johtajat, huonot liksa, kansa kärsii.

Esimerkit 21-24 nostavat esiin kansan kärsivänä ja köyhänä (kärsii nälkää, kuolee kurjuuteen). Kansa jää yhteiskunnassa osattomaksi (työttömänä) tai sitä nöyryytetään 
yhteiskunnassa (viedään leipä suusta). Kärsimyksen syy ei ole kansassa itsessään, vaan yhteiskunnallisissa oloissa (liksa, johtajat). Näissä esimerkeissä kirjoittajat ilmaisevat mielipiteensä vallitsevasta yhteiskunnallisesta tai poliittisesta tilanteesta. Tilanteet viittaavat nykyhetkeen tai menneeseen; esimerkki 24 viittaa lamanaikaisiin vaikeuksiin. Tällainen kärsimys ei kuitenkaan koske pelkästään Suomen kansaa:

25) Kreikan kansa on kuusi vuotta kärsinyt julmista leikkauksista, mutta velkojat vaativat yhä lisää.

26) Kreikan kansa on nälkäkuoleman partaalla ja siltä ei voi ummistaa silmiään, mutta poliitikot, jotka syyllistyivät tähän Kreikan kansanmurhaan on pantava pois viroistaan koko EU alueella ja heidät on tuomittava vankilaan rikoksista ihmisyyttä vastaan

Esimerkeissä 25-26 kriisi ei ole kotimainen, vaan Kreikan velkakriisi 2010-luvun vaihteessa. Kärsimyksen lisäksi kansa on köyhää meillä ja muualla:

27) Me köyhä kansa palataan kiljun keittoon ja ostetaan halpaa viinaa venäläisiltä ja virolaisilta trokareilta.

28) Neuvostoliittokin oli sosialistinen ja sen luonnonrikkaudet ovat maailman suurimmat, mutta kansa oli rutiköyhää.

Köyhyys ja kärsimys syntyvät nöyryytyksestä ja siitä, että kansaa petetään:

29) Suomalainen on otollinen kansa kusetukseen

30) Mutta kusetettu kansa

31) Kaikki etuudet pois, ja kansa kyykkyyn

Esimerkissä 29 kirjoittaja viittaa epäsuorasti kansan tyhmyyteen (otollinen kusetukseen), minkä vuoksi nöyryyttäminen on helppoa. Esimerkeissä 29-31 ei kuitenkaan mainita, kuka tai ketkä ovat nöyryyttäjiä, mutta se selviää muista yhteyksistä. Koska kansaa petetään monin tavoin, kansa joutuu myös maksamaan:

32) Ja kansa maksaa.

33) Ja kansa maksaa veroista.

34) Valtio maksaa=siis kansa maksaa.

35) Suomen kansa siis maksaa ja kreikkalaiset nauraa.

36) Kataisen virka maksoi siis Kuusi miljardia ja kansa maksaa koska kokomus [sic] niin päätti.

37） Juttu on niin että pankit ei luo mitään rahaa vaan pelkkää velkaa jonka kansa lopuksi maksaa.

Esimerkki 32 on toteamus maksajan velvollisuudesta. Muissa esimerkeissä (33-37) kirjoittajat mainitsevat, mitä tai mistä maksetaan (esim. veroista). Esimerkissä 35 tulee esille kirjoittajan katkeruus, joka kuvataan muiden pilkalla (kreikkalaiset nauraa). Aineistossa 
toistuu kansan alisteinen asema ja kansan kuvaaminen uhrina tai petettynä monin tavoin. Kansan maksumiehen rooli toistuu. Jotkut kirjoittajat eivät pidä tätä kuitenkaan kansan omana syynä, vaan syyllisiä ovat eliitin jäsenet:

38) Muutamien rikollismielisten johtajiemme ansiosta muu kansa joutuu kärsimään.

39) Voitot porvarien laariin ja köyhä kansa maksaa.

40) Tavallinen kansa on maksumies ja rikkaat nauravat ja poimivat vaan veronkevennyksiä.

41) Eliitti tuhlaa ja tavallinen kansa maksaa.

42) Kun kansa ajetaan köyhyyteen ja nälkäkuolemaan eliitin juhlat alkavat.

Näissä esimerkeissä kansa asetetaan vastakkain eliitin edustajien kanssa (johtajat, porvarit, rikkaat), jotka esitetään epärehellisinä ja pilkallisina (rikollismieliset, nauravat). Kansa esitetään esimerkeissä 38-42 poliittisten päätösten kohteena, eikä kansalla ole valtaa. Nämä kirjoittajat hakevat siis syytä kansan aseman heikkouteen. Esimerkeissä toistuu se, että kansa tuottaa eliitille varat (kansa maksaa - eliitti tuhlaa), mistä seuraa kirjoittajan mukaan äärimmäinen kärsimys (köyhyys, nälkäkuolema). On ilmiselvää, että kirjoittajat ilmaisevat tässä voimakasta erimielisyyttä vastakkainasetteluilla ja kärjistyksillä.

Tämän kaltainen puhe kansasta on samanlaista kuin populistinen diskurssi, jossa toimija esittää itsensä uhrina ja joka etsii vastustajia, jotka ovat syyllisiä (ks. lukua 2; Müller $2016,2)$. Kansalla ei ole valtaa, ja kansa jää myös politiikan ulkopuolelle:

43) Miksi kansa jaksaisi korvaansa heilauttaa tuollaisten pönöttyneiden proffien puheista.

44） Faktahan se on, että poliitikkojen päätökset ovat kaukana siitä mitä kansa haluaa.

45) Unohtui eu-kritiikki ja kansa kun oma vallanhimo vei voiton.

46) Eliitti unohtaa kansan ja omat periaatteet ja vaalilupaukset, kun pääsee valtaan.

Vastakkainasetteluun kuuluu, että eliitti nähdään vallanhimoisena eikä kansa ole syyllinen ongelmiin. Näissä merkityksissä on myös ironiaa (pönöttyneiden proffien) tai avointa ivaa (oma vallanhimo, eliitti unohtaa [...] omat periaatteet). Sama katkeruus ja alistuneisuuden käsittely näkyy esiintymissä, joissa kirjoittaja viittaa omaan kansaan:

47) Kuka elättäisi ne viis miljoonaa pakolaista, jos ja kun omakin kansa velkaantuu ja jotkut näkee ehkä jo nälkää.

48) Muun maalaiset elintasopakolaiset ovat tärkeämpia kuin oma kansa.

Esimerkeissä 47-48 vastakkainasettelu on oman kansan ja maahanmuuttajien välillä. Kansa nähdään yhtenäisenä ihmisjoukkona, joka kärsii. Kärsimys on myös aiheena niissä muutamissa viesteissä, joissa kirjoittaja viittaa tavalliseen kansaan: 
49) kreikan tavallinen kansa ole siihen syypää

50) Katkeruuteen on johtanu se, että Soinilla on varaa ruokailla eliittipaikoissa, kun tavallinen kansa näkee nälkää.

Tavallisen kansan merkitys on näissä esimerkeissä lähellä alistettua kansaa tai uhria.

Tässä luvussa esitettyjen esimerkkien kielellinen toiminta vaihtelee valittamisesta syytöksiin. Kansa asemoidaan uhrina, petettynä ja alistettuna toimijana, joka ei kykene yhteiskunnalliseen toimintaan. Kirjoittajat toistavat näkemystä ilman valtaa olevasta kansasta, joka joutuu rahoittamaan yhteiskunnan toiminnat, vaikka se ei sitä haluaisi. Kirjoittajat luovat vastakkainasetteluja toisaalta kansan ja eliitin edustajien, toisaalta maahanmuuttajien ja oman kansan välillä. Kirjoittajien käsitykset kansasta ovat myös paheksuvia ja väheksyviä (ks. lukua 2). Kyseessä on tyytymättömyyden diskurssi, jossa toimija on uhri tai kaltoin kohdeltu. Tässä esiintyy myös polarisoitunut maailma, jossa kirjoittaja hakee arveluttavia vastustajia kansalle. (Müller 2016, 42; ks. luku 2.)

\subsection{Poliittinen diskurssi: kansa haluaa valtaa}

Aineisto sisältää myös viestejä, joissa kansa esitetään toimijana. Näissä viesteissä kansalla on ainakin pyrkimys toimintaan kohti valtaa. Kansa esiintyy jonkin kognitiivisen verbin tai havaintoverbin, kuten tietää, havaita, tajuta, yhteydessä. Näistä selkeimpiä ovat tietääverbin kanssa esiintyvät tapaukset:

51) Kyllä kansa tietää!

52) mutta kyllä kansa tietää

53) Kyllä kansa tietää ja kateus opettaa

54） Kyllä kansa tietää mikä on Vennäjän [sic] uhka.

55) Nykyisenlainen maahanmuutto on täysin turha menoerä, joten on hyvä, että kansa tietää mihin sitä rahaa tuhlataan.

Kuten yllä olevista esimerkeistä 51-55 käy ilmi, kansa tietää -ilmaus toistuu erilaisissa yhteyksissä. Esimerkki 51 on yksittäinen, ilman muuta kontekstia esiintyvä lausuma. Se oli alun perin Suomen Maaseudun Puolueen vaalilause ja Veikko Vennamon lentävä lause (Wiberg 2011, 267). Se on stereotyyppinen, toteava ilmaus, jolle voidaan antaa myös ironinen merkitys, kun kirjoittaja vihjaa, että kansa ei ole täysin tietämätön. Esimerkeissä 54-55 tietäminen kohdistuu naapurivaltioon (Venäjä) ja maahanmuuton kustannuksiin. Näissä lauseissa tietämisen ilmaus voi toimia eräänlaisena varoituksena tai uhkauksena. Toisaalta kaikissa esiintymissä tietämisen kohde ei ole selvä, sillä aineiston perusteella ei ole aina mahdollista selvittää, mitä kansa oikein tarkalleen tietää. On mahdollista tulkita esimerkit 51-55 siten, että kirjoittaja laskee itsensä osaksi kansaa ja täten ilmaisee oman samanmielisen kantansa näiden lausumien kautta.

Tässä osassa aineistoa on myös tapauksia, joissa kansa esiintyy jonkinlaista havahtumista kuvaavan verbin kanssa: kansa huomaa, herää: 
56) Onneksi kansa viimein heräsi ja alkoi äänestämään oikein.

57） Mutta onneksi kansa viimein heräsi ja alkoi äänestämään oikein tietäen tasan tarkkaan missä on sosialisti tai kommari, siellä ei ole demokratian häivääkään jäljellä.

58) Niistä välittyy puolueen todellinen kuva ja tämän on kansa huomannut, se näkyy kannatuksen laskuna.

59) Hyvät ajat ovat Persuilla ohi, huijaus meni liian pitkälle, kansa huomasi asioiden todellisen tarkoituksen, oman edun tavoittelun.

Esimerkeissä 56-59 kirjoittajat esittävät menneisyyteen sijoittuneen poliittisen tilanteen, jossa kansa on oivaltanut jotakin ja josta on seurannut oikeanlainen poliittinen toiminta (äänestämään oikein, esimerkki 56). Kun kansa huomaa tai herää, siitä seuraa kirjoittajien tulkinnan mukaan oikeanlainen poliittinen toiminta, esim. Kansa heräsi - oikein äänestäminen.

Samanlaista tulkintaa kirjoittajat esittävät seuraavissa esimerkeissä, joissa he käyttävät kognitiivista tajuta verbiä:

6o) Kreikkalaiset päättäjät ja kansa ovat nyt tämän tajunneet.

61) Samaa kusetusta kaikki Persujen vaalipuheet kuin aina ennenkin, mutta nyt on onneksi Persujen kannatus kääntynyt laskuun, kansa on tajunnut joutuneensa kusetetuksi.

Samankaltainen toimintajärjestys esiintyy myös menneisyyteen sijoittuvien toimintojen kuvauksessa kyllästyä-verbin kanssa.

62) Lopulta [Venäjän] kansa kyllästyi valehteluihin ja kantoi kommunistit paskakaivoon.

63) Kun lipsuu lupauksista liian paljon, jossain vaiheessa kansa kyllästyy.

Aineistossa on myös esimerkkejä kansan poliittisesta toiminnasta, äänestämisestä ja sen seurauksista, jossa toiminta ilmaistaan verbillä äänestää:

64) Jos kansa olisi nyt viisas ja äänestäisi Soinin porukoita, korvausten saaminen olisi täysin varmaa.

65) Siksi kansa sangoin [sic] joukoin riensi äänestämään tätä ainoaa oikeaa puoluetta: Kokoomusta!

66) Jos kansa äänestää väärin, kuten Kreikassa, rangaistus on ankara.

Esimerkeissä 64 ja 66 esitetään toive (jos) jostakin asiantilasta ja jokaisessa esimerkissä 64-66 kansan toiminta kuvataan suhteessa äänestämiseen. Kansan toimintaa kuvataan myös kognitiivisella päättää-verbillä; näissä tapauksissa päätökset liittyvät myös yhteiskuntaan:

67) Demokraattisessa maassa kansa päättää. 
68) Onneksi Suomen kansa on päättänyt jo kauan sitten, että tätä maata ei vallata.

69) Toisinsanoen kansa päättää aivan konkreettisesti mitä se haluaa ja mitä ei ja hallintokoneistolla on sen jälkeen vain yksi tehtävä, nimittäin TOTEUTTAA KANSAN TAHTO.

Esimerkeissä 67-69 kansa esitetään demokratian toteuttajana, joka pystyy ohjaamaan kansakunnan kohtaloa itse. Esimerkissä 69 esitetään vaatimus yhteiskunnalle. Kansa on tässä yhtenäinen kansajoukko, jolla on oma tahto.

Aineistossa kansa yhdistetään myös puhetekoa kuvaaviin verbeihin sanoa ja puhua:

70) Eduskuntavaaleissa Suomen kansa sanoi NATO:lle ei.

71) Joten pulinat pois kansa on puhunut ja käyttänyt demokratian antamaa mahdollisuutta vaikuttaa ja ne toopet jotka eivät sitä ole käyttäneet voivat huutaa tuuleen niin paljon kuin tahtovat se vain ei auta mitään eikä johda mihinkään.

Nämä edustavat puheteolla tehtäviä poliittisia päätöksiä. Esimerkissä 70 käsitellään suomalaisten kantaa poliittisen äänestystilanteen jälkeen, esimerkki 71 kuvaa yleisempää näkemystä äänestyksen jälkeisestä tilanteesta.

Tässä alaluvussa analysoiduissa esimerkeissä kansan oivallusta seuraa oikeanlainen poliittinen toiminta eli näissä kirjoittajat arvioivat kansaa älykkäänä. Kansan älykkyys kohdistuu epäkohtiin, joita esiintyy poliittisessa järjestelmässä ja päätöksenteossa; tässä suhteessa nämä esimerkit edustavat tyypillistä populistista diskurssia (ks. lukua 2). Samoin tässä esitetty kuva kansasta on yhtenäinen: kirjoittajat ovat samaa mieltä kansan kanssa ja sen auktoriteettiin he tukeutuvat.

\subsection{Poliittinen diskurssi: kuva kansasta}

Aineistossa kansa esiintyy toisinaan myös positiivisissa konteksteissa, joissa kansaa kuvataan tai määritellään jollakin tavoin:

72) En usko siihen: Suomen kansa on ihan järkevää suurelta osin.

73) Suomalaiset ovat sivistynyt kansa, joka osaa myös englantia, joten eiköhän me osata ajatella omin aivoin.

74) Suomen kansa on rauhantahtoista - se on ihan totta. Suomessa on ollut katovuosia, puutetta ja nälkää ihan luonnonolosuhteiden vuoksi mutta sisulla kansa täällä selvisi.

Suomen tai muiden maiden kansoja määritellään järkeväksi, ei-tyhmäksi, vauraaksi, rehelliseksi, ryhdikkääksi, valveutuneeksi, viisaaksi, osaavaksi, vastuuntuntoiseksi, ystävälliseksi, ahkeraksi tai älykkääksi. Esimerkeissä 72-74 kansa ei ole uhri, petetty, eikä alistunut, vaan kirjoittajat arvostavat kansaa jonkin ominaisuuden tai keskustelun kohteena olevan asian 
vuoksi. Myös kirjoittaja kuuluu tähän kansaan (eiköhän me osata). Kirjoittajien arvioinnin kohteet vaihtelevat uskonnosta yhteiskunnallisiin asioihin.

Näiden lisäksi aineistossa on esiintymiä, joissa kansa viittaa johonkin kansakuntaan (ks. myös lukua 4):

75) Nouse jo oi Ranskan kansa kohtaamaan vihollises silmäst silmähän

76) Aikanaan sitten Venäjän kansa saa oman tuomionsa.

77) Ei venäjän kansa ole paha vaan venäjän johtajat on niitä jotka aiheuttavat konfliktit

Näissä esimerkeissä kirjoittajat määrittelevät kansakuntia. Esimerkit sisältävät poliittista tulkintaa, kuten esimerkeissä 76 ja 77, joissa kuvataan Venäjän eri aikojen yhteiskunnallista ja poliittista tilannetta.

\section{Lopuksi}

Tutkimustehtävänämme oli tarkastella, miten kansasta puhutaan Suomen suurimmalla keskustelupalstalla, Suomi24:ssä. Ensimmäiseksi tarkastelimme kansaan liittyviä avainsanoja ja merkitysryhmiä, joiden avulla pääsimme kiinni tilastollisin perustein aineistossa esiintyviin kansa-sanan diskurssiprosodioihin ja sitä kautta verkkokeskustelijoiden kansaan liittämiin diskursseihin. Diskursseista tavallisimmat olivat uskonto, politiikka ja valta, etnisyys ja yhteiskunta; uskonto oli näistä ehdottomasti yleisin. Tämä kertoo siitä, että kansa esiintyy usein uskonnollisessa kielessä. Erityisesti Raamatun tapahtumia käsittelevissä teksteissä käytetään usein viittauksia sanaan kansa puhuttaessa muun muassa uskonnollisista ryhmistä.

Politiikka ja valta -diskurssissa korostuivat hallintoon ja hallintoelimiin liittyvät sanat, itsenäisyys ja ideologiat. Ne näyttävät, että kansa liitetään vahvasti edelleen itsenäisyyteen ja ajatukseen yhdestä kansasta ja yhdestä maasta. Lisäksi negatiivisesti sävyttyneissä epätasa-arvoon liittyvissä merkitysryhmissä näkyy yhtäältä populismi, mutta toisaalta myös historiassa tavattu käsitys kansasta vähempiosaisena. Pienen etnisyysmerkitysryhmän sisältämät kansalaisryhmiä merkitsevät avainsanat kertovat kansalaisryhmien olevan myös tärkeä osa siitä, miten kansa verkkokeskusteluissa käsitetään. Samoin kuin politiikkaan ja valtaan liittyvät avainsanat, myös yhteiskunta-merkitysryhmän avainsanat liittyvät kirjoittajien käsityksiin yhteiskunnan kahtiajaosta ja epätasa-arvosta.

Toinen tutkimuskysymyksemme koski sitä, miten verkkokeskustelun kirjoittajat representoivat ja asemoivat kansaa eri diskursseissa; tarkastelussa olivat uskonnollinen, poliittinen ja yhteiskunnallinen diskurssi. Kansa asemoitiin uskonnollisessa diskurssissa historiallisena tai raamatullisena kansana. Kansa oli myös uskova kansa, johon joukkoon kirjoittajat kuuluivat. Kirjoittajat ilmaisivat erimielisyyttä, kyseenalaistusta tai syytöstä ei-uskonnollista käytöstä kohtaan. Poliittinen ja yhteiskunnallinen diskurssi jakautuivat 
kahtia: kansaan, jolla ei ole valtaa tai joka pyrkii kohti sitä. Ilman valtaa olevaa kansa kuvattiin tyhmäksi kansaksi huudahduksissa, toteamuksissa tai retorisissa kysymyksissä. Kirjoittajien ilmaisema kielellinen toiminta oli tässä tapauksessa pääasiassa joko valitus tai syytös, joilla he osoittivat paheksuntaansa ja väheksyntäänsä kansaa kohtaan. Tyhmä kansa oli yhteiskunnan ulkopuolinen, ymmärtämätön ja sivistymätön, eivätkä kirjoittajat kuuluneet tähän joukkoon. Kansa oli myös vailla valtaa tapauksissa, jotka osoittivat kansan uhrina, petettynä ja alistettuna. Näissä kirjoittajat valittavat ja syyttävät, ja he ovat tyytymättömiä asemaansa. Kansa uhrina asemoidaan vastakkain yhteiskunnan eliitin kanssa: kirjoittajat vastustivat eliittiä ja pitivät eliittiä vääryyden syynä. Kun kansa pyrki kohti valtaa, se asemoitiin toimijaksi. Tässä kirjoittajat käyttivät havainto- ja puhetekoverbejä, sekä episteemisyyttä ilmaisevia verbejä, kuten tietää. Kirjoittajat kuuluivat tähän kansaan, joka on älykäs ja joka on havainnut epäkohdat järjestelmässä ja toiminut sen mukaisesti. Viimeinen asemointi oli suhteellisen positiivinen kuva kansasta poliittisessa diskurssissa. Tällöin kansa kuvattiin kansakuntana (Suomen kansa) tai jonkinlaisena ihmisjoukkona, esimerkiksi sivistyneenä tai sisukkaana kansana.

Kansaa koskevat merkitykset antavat kirjoittajille mahdollisuuden rakentaa omakuvaa, erottautua tai legitimoida asemaansa siten, että toiset kirjoittajat tunnistavat yhteisen jaetun representaation (ks. van Dijk 2006, 121). Analyysin perusteella kansan representaatiot sisältävät stereotyyppistä ja yleistävää, tuttua diskurssia, joka toistaa olemassa olevia käsityksiä kansasta.

\section{Lähteet}

Aller Media Oy 2014: Suomi 24 -korpus (2016H2) [tekstikorpus]. Kielipankki. Saatavilla http://urn.fi/ urn:nbn:fi:lb-2017021506

ANDERSON, BENEDICT 1983: Imagined Communities: Reflections on the Origin and Spread of Nationalism. Verso, London.

Anttila, Anu-Hanna - Kauranen, Ralf - Löytty, Olli - Pollari, Mikko - Rantanen, Pekka - Ruuska, Petri 2009: Kuriton kansa: Poliittinen mielikuvitus vuoden 1905 suurlakon ajan Suomessa. Vastapaino, Tampere.

Anttonen, Pertti 2005: Tradition through Modernity. Postmodernism and the Nation-State in Folklore Scholarship. Finnish Literature Society, Helsinki. https://doi.org/10.21435/sff.15

Apo, SATU 1995: Naisen väki. Tutkimuksia suomalaisten kansanomaisesta kulttuurista ja ajattelusta. Hanki ja Jää, Helsinki.

1998: Suomalaisen stigmatisaation traditio. Pertti Alasuutari ja Petri Ruuska (toim.): Elävänä Euroopassa: Muuttuva suomalainen identiteetti, 83-128. Vastapaino, Tampere.

Arendholz, Jenny 2017: Message boards 2017. Christian R. Hoffman ja Wolfram Bublitz (toim.): Pragmatics of Social Media, 125-149. Mouton de Gruyter, Boston/Berlin.

Charaudeau, Patrick 2005: Le discours politique. Les masques du pouvoir. Vuibert, Paris.

2011: Réflexions pour l'analyse du discours populiste. Mots. Les langages du politique, 97. Saatavilla http://mots.revues.org/20534

COUPLAND, NiKolaS 2014: Sociolinguistic change, vernacularization and broadcast British media. JANNIS Androutsopoulos (toim.): Mediatization and Sociolinguistic change, 67-97. Walter de Gruyter, Berlin. https://doi.org/10.1515/9783110346831.67

Creswell, John W. 2013: Research Design: Qualitative, Quantitative, and Mixed Methods Approaches. 
Sage, Los Angeles.

Dijck, José van - Poell, Thomas 2013: Understanding Social Media Logic. Media and Communication $1(1), 2-14$.

DijK, Teun VAn 2006: Ideology and discourse analysis. Journal of Political Ideologies 11 (2), 115-140.

DuBois, John 2007: The Stance Triangle. Robert Englebretson (toim.): Stancetaking in Discourse. Subjectivity, Evaluation and Interaction, 139-182. John Benjamins, Amsterdam/Philadelphia.

Fairclough, Norman 1992: Discourse and Social Change. Polity Press, London.

Goffman, ERving 1990 [1959]: The Presentation of Self in Everyday Life. First published by Anchor Books, USA, 1959. Penguin Books, London.

Gumperz, John 1992: Contextualization revisited. Peter Auer ja Aldo di Luzio (toim.): The Contextualization of Language, 123-154 John Benjamins, Amsterdam/Philadelphia. https://doi. org/10.1075/pbns.22.04gum

Harré, Rom - van Langenhove, Luk (toim.) 1999: Positioning Theory: Moral Contexts of International Action. Blackwell, Oxford.

Helasvuo, Marja-Liisa - Johansson, Marjut - Tanskanen, Sanna-Kaisa 2014: Johdatus digitaaliseen vuorovaikutukseen. Marja-LiIsa Helasvuo, Sanna-Kaisa Tanskanen ja Marjut JoHANSSON (toim.): Kieli verkossa: näkökulmia digitaaliseen vuorovaikutukseen, 9-28. Suomalaisen Kirjallisuuden Seura, Helsinki.

Hoffmann, Christian R. 2017: Log in: Introducing the pragmatics of social media. Christian R. Hoffmann ja Wolfram Bublitz (toim.): Pragmatics of Social Media. De Gruyter Mouton, Berlin/Boston.

Hunston, SUSAn 2007: Semantic prosody revisited. International Journal of Corpus Linguistics 12 (2), 249-268. https://doi.org/10.1075/ijcl.12.2.09hun

JANTUNEN, JARMo H. 2011: Avainsana-analyysi annotoidun oppijankieliaineiston tutkimisessa: Alustavia havaintoja. Esa Lehtinen, Sirkku Aaltonen, Merja Koskela, Elina NevasaAri ja MariANN SKog-SöDERSved (toim.): AFinLA-e, Soveltavan kielitieteen tutkimuksia 3, 48-61. Saatavilla https://journal.fi/afinla/article/view/4456

— painossa: Korpusavusteinen diskurssianalyysi (CADS): analyysiesimerkki homouden ja heterouden digitaalisista diskursseista. LAUri HaAPANen, LiIsA KäÄntä ja LotTA Lehti (toim.): AFinLA-e, Soveltavan kielitieteen tutkimuksia 11.

Johansson, Marjut 2017: Everyday opinions in news discussion forums: Public vernacular discourse. Discourse, Context and Media 19, 5-12. https://doi.org/10.1016/j.dcm.2017.03.001

Johansson, Marjut - Kyröläinen, Aki-Juhani - Ginter, Filip - Lehti, Lotta - Krizsán, Attila -Laippala, Veronika 2018: Opening up \#jesuisCharlie. Anatomy of a Twitter discussion with mixed methods, Journal of Pragmatics (129), 90-101.

KaUranen, Kaisa 2013: Mitä ja miksi kansa kirjoitti? Lea Laitinen ja Kati Miknola (toim.): Kynällä kyntäjät. Kansan kirjallistuminen 1800-luvun Suomessa, 19-54. Suomalaisen Kirjallisuuden Seura, Helsinki.

Karkama, Pertti 2001: Elias Lönnrot ja ajan aatteet. Kansakunnan asialla. Suomalaisen Kirjallisuuden Seura, Helsinki.

KLEINKE, SONJA 2010: Interactive aspects of computer-mediated communication. Disagreement in an English and German public news group. Sanna-Kaisa Tanskanen, Marja-LiIsa Helasvuo, Marjut Johansson ja Mia Raitaniemi (toim.): Discourses in Interaction, 195-222. John Benjamins, Amsterdam/Philadelphia. https://doi.org/10.1075/pbns.203.15kle

Knuuttila, Seppo 1992: Tyhmän kansan teoria. Näkökulmia menneestä tulevaan. Suomalaisen Kirjallisuuden Seura, Helsinki.

1994: Kansanhuumorin mieli. Kaskut maailmankuvan aineksena. Suomalaisen Kirjallisuuden Seura, Helsinki.

2008 [1982]: Yksilö ja yhteisö - perinnetieteiden yhteiskunta? Seppo Knuuttila, Ulla Piela ja SiniкKa VAкімo (toim.): Entinen aika, nykyinen mieli, 404-416. Suomalaisen Kirjallisuuden Seura, Helsinki. 
KS = Kielitoimiston sanakirja . Kotimaisten kielten keskuksen verkkojulkaisuja 46. Kotimaisten kielten keskus ja Kielikone Oy, Helsinki.

KuRKi, TuUlikKI 2002: Heikki Meriläinen ja keskusteluja kansanperinteestä. Suomalaisen Kirjallisuuden Seura, Helsinki.

Lagus, Krista - Pantzar, Mika - Ruckenstein, Minna - Ylisiurua, Marjoritikka 2016: Suomi24. Muodonantoa aineistolle. Helsingin yliopisto, Helsinki.

Lappalainen, Pertti 2002: Poliittisen tyylin taito. Vastapaino, Tampere.

Latvala, Paulinna 2013: Kerrottu politiikka. Muistitietotutkimus arjen polittisesta kulttuurista. Suomalaisen Kirjallisuuden Seura, Helsinki.

LeE, DAvid 2008: Corpora and discourse analysis. New ways of doing old things. Vijay Bhatia, John Flowerdew ja Rodney Jones (toim.): Advances in Discourse Studies, 86-99. Routledge, London.

Levinson, Stephen 1992: Activity type and language. Paul Drew ja John Heritage (toim.): Talk at work. Interaction in Institutional Settings, 66-100. Cambridge University Press, Cambridge.

LiIKANen, ILKKa 2003: Kansa. Fennomanian kansa-käsite ja modernin politiikan kieli. MatTi HyvärInen, Jussi Kurumäki, Kari Palonen, Tuija Pulkkinen ja Henrik Stenius (toim.): Käsitteet liikkeessä. Suomen poliittisen kulttuurin käsitehistoria, 257-307. Vastapaino, Tampere.

Luotolahti, Juhani - Kanerva, Jenna - Laippala, Veronika - Pyysalo, Sampo - Ginter, Filip 2015: Towards universal web parsebanks. Proceedings of the International Conference on Dependency Linguistics (Depling'15), 211-220. Uppsala University, Uppsala.

McEnery, Tony - Xiao, Richard - Tono, Yukio 2006: Corpus-based Language Studies. An Advanced Resource Book. Routledge, London.

MiккоцA, Kaтi 2009: Tulevaisuutta vastaan. Uutuuksien vastustus, kansantiedon keruu ja kansakunnan rakentaminen. Suomalaisen Kirjallisuuden Seura, Helsinki.

Müller, Jan-Werner 2016: What Is Populism? University of Pennsylvania Press, Philadelphia.

PAPACHARISSI, ZIZI 2014: On networked publics and private spheres in social media. ThereSA M. SENFt ja Jeremys Hunsinger (toim.): The Social Media Handbook, 109-119. Routledge, London ja New York.

Partington, Alan - Duguid, Alison - Taylor, Charlotte 2013: Patterns and Meanings in Discourse. Theory and Practice in Corpus-assisted Discourse Studies (CADS). John Benjamins, Amsterdam/Philadelphia.

PÖYsä, JYRKI 1997: Jätkän synty. Tutkimus sosiaalisen kategorian muotoutumisesta suomalaisessa kulttuurissa ja itäsuomalaisessa metsätyöperinteessä. Suomalaisen Kirjallisuuden seura, Helsinki.

SCott, Mike - Christopher, Tribble 2006: Textual Patterns: Key words and Corpus Analysis in Language Education. John Benjamins, Amsterdam/Philadelphia.

Sinclair, John 1996: The Search for Units of Meaning. Textus IX, 75-106.

Stubbs, Michael 2001: Words and Phrases. Corpus Studies of Lexical Semantics. Blackwell, Oxford.

Tervonen, Mirka 2014: Historiankirjoitus ja myytti yhden kulttuurin Suomesta. Pirjo Markkola, Hanna Snellman ja Ann-Catrin Östman (toim.): Kotiseutu ja kansakunta. Miten suomalaista historiaa on rakennettu, 137-162. Suomalaisen Kirjallisuuden Seura, Helsinki.

Thurlow, Crispin - Mroczek, Kristine R. 2011: Introduction. Fresh Perspectives on New Media Sociolinguistics. Crispin Thurlow ja Kristine R. Mroczek (toim.): Digital Discourse. Language in the New Media, xliv-xliv. Oxford University Press, New York.

TieteEn TERMiPANKKI 2017. Saatavilla http://www.tieteentermipankki.fi

TOPelius, Zacharias 1876: Maamme kirja. Lukukirja alimmaisille oppilaitoksille Suomessa. G. W. Edlund, Helsinki.

Weizman, Elda 2008: Positioning in Media Dialogue. John Benjamins, Amsterdam/Philadelphia. https:// doi.org/10.1075/ds.3

Wiberg, Matti 2011: Politiikan sanakirja. Inhorealistin versio. Siltala, Helsinki.

Östman, Jan-Ola - Virtanen, Tuija 2011: Text and discourse linguistics. Jan Zienkowski, Jan-Ola Östman ja Jef Verschueren (toim.): Discursive Pragmatics, 266-285. John Benjamins, Amsterdam/Philadelphia. 


\section{Marjut Johansson, Jarmo H. Jantunen, Anne Heimo, Mirka Ahonen and VERONIKA LAIPPALA: kansa 'a/the people' in digital discourse: Corpus-assisted dis- course analysis in the Suomi24 discussion forum}

The objective of this paper is to analyse how participants in the largest discussion forum in Finland called Suomi24 use the word kansa 'a/the people'. Our main research questions are: 1) What kinds of discourses the forum participants relate to kansa to and 2) what kinds of representations the participants associate to kansa and what kinds of meanings they construct for the term in the discussion forum.

Our theoretical and methodological approach is based on corpus-assisted and digital discourse analysis. Studying the data from two different perspectives with two different methods will give two complementary views on the use of kansa in discourse. In the first part of the study, we analysed the 2.4-billion-token Suomi24 data in its entirety, applying corpus-assisted discourse and keyword analysis in order to analyse the discourses and representations that the discussion participants associate with to kansa. For this, we extracted all paragraphs where the lemma kansa was used. Altogether, the data contain about 829,000 occurrences of the lemma.

In the second phase, we executed qualitative digital discourse analysis wherein we focused on the positioning of the kansa by examining the type of linguistic action in the utterances where it was used. This includes what kind of relation and agreement or disagreement forum participants expressed in relation to the topic they were writing about.

The first analysis showed that the most frequent discourse topics associated with kansa were religion, politics and power, ethnicity and society. These topics indicate that kansa is often represented through religion and that kansa in the discourses is strongly related to the nation-state, that is, independence, government and ethnic groups. Furthermore, kansa is often associated with inequality in society, as a part of the people are seen as disfavoured.

The second analysis, based on digital discourse analysis, reveals that the word kansa is used in five ways. First, kansa is positioned in either a biblical sense or as religious people who blames others. Secondly, forum participants call them stupid people and they complain and place blame while showing disregard towards the people. For the third way, the people was described as victim, betrayed and oppressed without access to power, wherein the participants complain and make accusations. Fourthly, through the use of both cognitive and speech act verbs, the people were described as a social actor that shows intelligence which the forum participants are a part of. The last category is mixed, having people as a representative of a nation or described with having some type of quality, such as sisukas kansa ('a persistent people' or 'a people with perseverance').

The results show that kansa ('a/the people') is used in very familiar and stereotypical ways. This word functions as part of an ideological discourse that allows participants to build their self-image, distinguish themselves from the people or legitimise their own position in a way that other participants recognise the shared and reproduced representation of the people. This representation is thus part of a new kind of public vernacular discourse produced by ordinary people on various social media platforms. However, these representations of kansa did not present any novel ways of understanding people. 
Marjut Johansson marjut.johansson@pp.inet.fi Kieli- ja käännöstieteiden laitos 20014 Turun yliopisto

Anne Heimo anne.heimo@utu.fi Historian, kulttuurin ja taiteiden tutkimuksen laitos 20014 Turun yliopisto
Jarmo H. Jantunen jarmo.h.jantunen@jyu.fi Kieli- ja viestintätieteiden laitos, suomen kieli 40014 Jyväskylän yliopisto

Mirka Ahonen mimaah@utu.fi

Kieli- ja käännöstieteiden laitos 20014 Turun yliopisto

Veronika Laippala veronika.laippala@utu.fi Kieli- ja käännöstieteiden laitos 20014 Turun yliopisto 